\title{
INTERNAL VERSUS EXTERNAL LOCUS OF CONTROL AMONG STUDENTS IN TERTIARY EDUCATIONAL INSTITUTIONS: A REVIEW OF RELATED LITERATURE AND IMPLICATIONS FOR EDUCATIONAL PSYCHOLOGY
}

\section{MUDASSIR IBRAHIM GATAWA AND IBRAHIM YUSUF}

\begin{abstract}
This paper examined issues related to the search for means of improving performance among learners through explaining one of the psychological basis of academic achievement, that is, Locus of Control (LOC) which is a personality variable. The concept and different orientations of LOC were discussed. The issue of age, familial origins and gender with relevance to LOC were discussed. The desirability or otherwise of the internal and external LOC was also discussed. The paper concluded that higher external orientation and higher internal orientation could lead to anxiety and frustration in some instances. Implications for Educational Psychology were raised, which included counselling students to realize their mistakes, so that they don't attribute their expected failures to the teacher or something else. They should also be counselled not to set unachievable goals that when effort put in place failed, the situation would not result into anxiety and frustration.
\end{abstract}

\section{Introduction}

Academic performance is interestingly an important issue; a fundamental premium upon which all teaching-learning activities are measured using some criteria of excellence which include: good academic performance, poor academic performance, and academic failure (Tella, Tella, \& Adeniyi, 2009). The search for means of improving performance has made it imperative for researchers to explore the psychological bases of academic achievement, one of which is LOC of learners. Thus, the concept of LOC as a personality variable is now an important theoretical and applied research field, studied in connection with several phenomena.

Researchers such as Adeyemo (2001, 2005), Aremu (2000), Yoloye (2004), Zimmerman (2000) and Bong and Skaalvik (2003) have reported that academic performance is associated with socio-psychological variables. To them, one of the socio-psychological variables is LOC. Moreover, Amadi (2010) and Araromi (2010) in their separate studies posit that both internal and external LOC are important in academic performance. Araromi defines LOC as the extent to which an individual believes that he or she has control over an outcome.

The researchers as teachers have observed that in many instances some students in tertiary educational institutions who happened to get higher grades claim to have obtained it by themselves. While those with lower or failed grades claim to have been failed by their teachers, using a popular statement. "The teacher has failed me". The question of how this variable can be managed to improve academic performance of the learners is still a complex one. In the light of this, this research focuses on LOC among students in tertiary educational institutions.

\section{Theory of Locus of Control}

In an effort to explain how personal characteristics interact with the environment to predict behaviour, the psychologist Julian B. Rotter proposed a theory of LOC in 1954. Although Rotter emphasized both personal and environmental factors in behavioural 
prediction, much of the research generated by his theory focused on the role of people's expectancies or their subjective estimates of how likely it is that a given behaviour will lead to a desired outcome (Rotter, 1966).

According to Rotter, there are two types of expectancies. Specific expectancies apply to single situations, such as whether a student expects to do well in exam. Over time people learn to apply their expectancies to a variety of related expectancies, resulting in generalized expectancies. A generalized expectancy might refer to how well a student expects to do in exams in all of his or her courses. Rotter proposed that one of the most important generalized expectancies is a person's Locus of Control (LOC) (Rotter, 1966).

LOC refers to the perceived location of reinforcement sources for a person -that is, who or what is responsible to the things that happen to a person. As such, it is related to other control-related constructs, such as attribution and self-efficacy. Those with an internal LOC expect the important things in their lives to occur because of their own effort, skills, or abilities. Individuals with an external LOC expect these things to occur because of outside forces (such as luck, fate, chance, or powerful others) (Rotter, 1966).

Individuals with a high internal LOC believe that events in their lives derive primarily from their own actions; for example, when receiving test results, individuals with a high internal locus of control would praise or blame themselves and their abilities, where as individuals with a high external LOC would praise or blame the teachers or the test (Rotter, 1966).

\section{Concept of Locus of Control}

In personality psychology, locus of control refers to the extent to which individuals believe that they can control events that affect them. It is also seen as an individual's perception about the underlying main causes of events in his or her life (Rotter, 1966). The understanding of the concept was developed originally by Julian B. Rotter in 1954 and has since become an aspect of personality studies. A person's "locus" (Latin for "place or location") is conceptualized as either internal (the person believes they can control their life) or external (meaning they believe that their decision and life are controlled by environmental factors which they cannot influence) (Rotter, 1966).

Locus of control is a psychological variable, which refers to the extent to which a person feels he has control over his own destiny (Gbonee 2013). According to Njus \& Brockway (1999) LOC is an individual's belief regarding the causes of his or her experiences and the factors to which that person attributes success or failure.

The full name Rotter gave the construct was Locus of Control of Reinforcement. In giving it this name, Rotter was bridging behavioural and cognitive psychology. Rotter's view was that behaviour was largely guided by "reinforcements" (with rewards and punishments, individuals come to hold beliefs about what causes their actions) these beliefs, in turn, guide what kinds of attitudes and behaviours people adopt (Hans, 2000).

According to Carlson (2007) individuals with a high internal LOC believe that events in their life derive primarily from their own actions; for example, when receiving test results people with an internal LOC would praise or blame themselves and their abilities, 
whereas people with a high external locus of control would praise or blame the teacher or the test.

Thus, Locus of Control is concerned with the individual's generalized expectations concerning where control over subsequent events resides. In other words, who or what is responsible for what happens. It is analogous to, but distinct from, attributions (Fakeye, 2011). According to Amadi (2010) the "attribution theory assumes that people try to determine why people do what they do, i.e, attribute cause to behaviour". There are three stages which underly an attribution. Step one: the person must perceive or possibly observe the behaviour. Step two is to try and figure out if the behaviour was intentional, and step three is to determine if the person was forced to perform that behaviour. The latter occurs after the fact, that is, they are explanations for events that have already happened. Expectancy, which concerns future events, is a critical aspect of LOC.

Herbert (1982) maintained that attribution theory has had an influence on locus of control theory, but differences exist between the two. Attribution theorists have been (largely speaking) social psychologists (concerned with general processes characterizing how and why people make the attributions they do), whereas LOC theorists have been more concerned with individual differences.

Tella, Tella and Adeniyi (2009) explained that attribution theory is concerned with the study of how individuals explain events that take place in their lives. Attributions or causal perceptions and interpretations of behavioural outcomes are also based on person's learning history (Boekaerts, Otten, and Voeten, 2003).

Fakeye (2011) maintained that expectancy, which concerns future events, is a critical aspect of LOC. Locus of control is, therefore, grounded in expectancy- value theory, which describes human behaviour as determines by perceived likelihood of an event or outcome occurring contingent upon the behaviour in question, and the value placed on that event or outcome. Specifically, expectancy-value theory states that if (a) someone values a particular outcome and (b) that person believes that taking a particular action will produce that outcome, then (c) they are more likely to take that particular action.

Also, according to Vroom (1964), in expectancy theory three things remained considerable:

i. There is positive correlation between effort and performance

ii. Favourable performance will result into a desirable results, and

iii. The reward will satisfy an important need.

LOC should also not be confused with self-efficacy, which is a person's belief that he or she can accomplish a particular activity. Though it is a related concept, but differs from LOC by relating to competence in circumscribed situations and activities (rather than more general cross-situational beliefs about control).

\section{Personality Orientation}

Rotter (1975) cautioned that internality and externality represent two ends of a continuum, not a typology. Internals tend to attribute outcomes of events to their own control. People who have internals LOC believe that the outcomes of their actions are 
results of their own abilities. Internals believe that their hard work would lead them to obtain positive outcomes. They also believe that every action has its consequence, which makes them accept the fact that things happen and it depends on them if they want to have control over it or not. Externals attribute outcomes of events to external circumstances. People that have external LOC believe that many things that happen in their lives are out of their control. They believe that their own actions are a result of external factors that are beyond their control.

Gbonee (2013) reported that the feeling of control could be conceived to spread out along a continuum. At one end of the continuum, the internal control connotes the attitude that one can manipulate his environment for reinforcement. This is based more on one's potential effort or skill. That is, if the person has the influence of internal control, he believes that all that can come to him will depend on his personal effort and struggle. Such individual sees himself as instrumental in outcomes of events. On the other end of the continuum, the external control consists of a self attitude characterized by the feeling that all that happens to the individual is the consequence of chance, luck, fate and several others, all of which are forces and events beyond the individual's control.

Since the concept of LOC indicates the degree to which an individual perceives that they have control over their environment, it is logical to expect that the externally oriented person will differ in behaviour and achievement from the internally oriented person in several respects (Gbonee, 2013).

It is also asserted that the internally controlled person blames himself for his failure and accepts praise as deserves his triumphs. Students in different situations, based on this concept, perceive things differently as a result of their control. A discipline and selforiented student sees failure as his own inadequate preparation and efforts. Such a student blames himself for not putting in more efforts to succeed.

The externally controlled person will not think his successes and failures are caused by himself. He does not blame himself for his errors. Similar circumstances in school give the student a condition to curse and blame his teacher for his failure (Gbonee, 2013).

\section{Occasionally, students are heard saying}

"I blame my star for the failure or poor performance on that test," "whom did I meet that brought such bad luck to me in this test". Such student tends to shift his failure to an unknown source. But the internally controlled student would always say "I blame myself for the poor performance on the test" or "I did not prepare well enough for this test". The students are therefore, affected by their internal or external influences of LOC.

Consequently, the internal student is bound to change or improve, since he attributes his poor performance to his effort but not luck or powerful others beyond his control. While the externally controlled is bound to deteriorate and may not change to improve since he attributers failure or poor performance to luck or forces unknown, and may not be able to control it and to effect a change.

However, regarding LOC, there is another type of control which entails a mix among the internal and external types. People that have the combination of the two types of LOC are often referred to as $\mathrm{Bi}$-locals. People that have Bi-local characteristics are known to 
handle their case and cope with their problems more effectively by having the mixture of internal and external LOC. People that have this mix of locus of control can take personal responsibility for their actions and the consequences thereof while remaining capable of relying upon and having faith in outside resources. These characteristics correspond to the internal and external locus of control, respectively (Jocobs-Lawson, 2011).

\section{Familial Origins}

The development of LOC is associated with family style and resources, cultural stability and experiences with effort leading to reword. Many internals have grown up with family modeling, typical internal beliefs; these families emphasized effort, education, responsibility and thinking, and parents typically gave their children rewards they had promised them. In contrast, externals are typically associated with lower socioeconomic status. Societies experiencing social unrest increase the expectancy of being out-of control; therefore, people in such societies become more external (Suchultz \& Schultz, 2005).

Suchultz and Suchultz (2005) also reported that studies have shown that children whose parents had an external LOC are more likely to attribute their successes and failures to external causes. Warmth, supportiveness and parental encouragement seem to be essential for development of an internal LOC.

\section{Age}

It is sometimes assumed that as people age they will become less internal and more external. Tucker, Hamayan and Genesse (2006) believe that people become more internal as they get older. Schultz and Schultz (2005) reported that studies have indicated that LOC increases in internality until middle age. The authors also note that attempts to control the environment has become more pronounced between the ages of eight and fourteen. Mamlin, Harris and Case (2001) report that as people get older they tend to become more internal.

\section{Gender-Based Differences}

As Schultz and Schultz (2005) point out, significant gender differences in LOC have not been found for adults in the U.S population. However, these authors note that there may be specific sex-based differences for specific categories of items to assess LOC; for example, men may have a greater internal locus for questions related to academic achievements. Slagvold (2008) asserted that women are more internal in LOC than men. Oludipe (2013) reported that females tend to be more internal than males.

According to Mamlin, Harris and Case (2001) male tend to be more internal than females.

\section{Internal Versus External Locus of Control}

Rotter (1966) was of the opinion that Internals tend to exhibit greater efforts and interest in achievement related activities than do externals. Whyte (1980) had correlated with the academic successes of students enrolled in high-education courses. Students who were more internally controlled believed that hard work and focus would result in successful academic progress, and they performed better academically. Those students who were 
identified as more externally controlled (believing that their future depended upon luck or fate) tended to have lower academic-performance levels.

Furthermore, Leone and Burns (2000) were of the view that internals are more inclined than externals to perceive their behaviour as instruments in obtaining desired outcomes and avoiding undesirable outcomes. Dollinger (2000) reported that internals surpass externals on incidentally acquired and seemingly trivial knowledge which nevertheless has relevance for learners' academic success.

Amadi, (2010) reported that students with internal locus of control earn better grades work harder, and spend more time on home work as well as studying longer for test. Sharmmen (2004) reported that children who have an internal LOC tend to have higher levels for academic achievement than those with external LOC.

Grimes, Millea, and Woodruf (2004) in their study examined the connection between LOC and students evaluations of teaching. The study found that students with an internal LOC were more likely to complete above-average teacher evaluations, while students with an external LOC were more likely to give teachers average or below-average evaluations.

Downess (2008) reported that students with an internal LOC preformed significantly better than those with an external LOC.

Awofala, Awofala, Fatade and Nneji (2012) stated that internal LOC is an essential factor for students to have a thorough understanding of science and mathematics. According to them, internals are more likely to develop an intrinsic orientation in which participation in the science tasks present or because participation brings feelings of competence, mastery, control and self determination. According to Oludipe (2013) the individuals with an internal LOC were reported to:

i. Engage in activities that will improve their situation

ii. Emphasize striving for achievement

iii. Work hard to develop their knowledge, skills and abilities

iv. Are inquisitive and

v. Try to figure out why things turned out the way the did

vi. Take note of information that they can use to create positive outcomes in the future

vii. Have a more participating management style

viii. Manage the drawbacks of a strong internal locus of control and

ix. Are generally more successful.

Mamlin, Harris, and Case (2001) have cautioned people against lapsing in the overly simplistic view notion that are internal is good while an external is bad as there are important subtleties and complexities to be considered. Similarly, Fakeye (2011) explained that it is controversial in the field of psychology to hold the belief that internal LOC is desirable while external LOC is undesirable and vice-versa. It is assumed that the two subtleties are desirable depending on the circumstances surrounding the action or event. In learning situation, internal orientation need to be accomplished by competence, self efficacy and opportunity. On the other hand, it is believed that an internal who lacks 
competence, self-efficacy and opportunity can become neurotic, anxious and depressed (Fakeye, 2011).

According to Gbonee (2013), since external control consists of self attitude characterized by the feeling that all that happens to the individual is the consequence of change, luck, fate and several others, all of which are forces and events beyond the individuals control. Beliefs in this category had frustrated many individuals in life, as many have left to strive hard and live a comfortable life, and had attributed their ineffectiveness in attaining their desired goals to things unknown.

\section{Conclusion}

LOC affects achievement as a predictor of persistence in education. Both internal and external LOC are linked with desirability, but over relying on either end of the continuum is associated with anxiety and frustration. Therefore, the third type (Bi-Local) should be an alternative.

\section{Implications for Educational psychology}

External control oriented individuals should be counselled by psychologists not to either avoid or neglect striving hard or to remain idle for thinking of having an alternative that their ineffectiveness in attaining their desired goals could be attributed to external forces or things unknown. Such things could result into anxiety and frustration. Therefore, they should have the elements of striving hard, even when anticipating that luck and fate could determine their success.

Internal control oriented individuals should also be counselled that even though their own efforts stand good, they need to develop more competency, self-efficacy, and opportunity to enable them attain their desired goals. Because lack of competence, self-efficacy and opportunity could render them neurotic, anxious and depressed.

Generally, students should be enlightened on how they could develop their own efforts, study habit, and the relationship of such to fate, luck and other forces in attaining the goals. As hard work leads to success and vice-versa, actions and decisions could be part of one's fate. In many instances efforts coincide with luck. This would likely make the individuals to assume the third orientation of locus of control (Bi-Local).

Psychologists should also counsel students on how they could set achievable goals in relation to the efforts they make. Students should be made to realize where they make mistakes, so that they don't attribute their expected failure to the teachers or something else. Lastly teachers should be counselled to give students opportunity to participate in the class, and give the tasks that are within their ability. 


\section{References}

Adeyemo, D.A (2001). Self-efficacy and Subject Enrolment in Secondary schools: An empirical inquiry. Ibadan Journal of Education studies, 1(1): 86-95.

Adeyemo, D.A (2005). Parental Involvement, Interest in Schooling and School Environment as Predictors of Academic Self-efficacy among Fresh Secondary School Students in Oyo state, Nigeria. Electronic Journal of Psychology of Education, 5 (3): 115.

Amadi, M. (2010). Effective Determinants of ESL Success. Unpublished MEd Dissertation University of Ibadan.

Araromi, M. (2010). Motivation, Verbal Ability, Attitude, Gender and Locus of Control as Predictors of Academic Achievement in French Language, A Seminar Paper. University of Ibadan.

Aremu, A.O. (2000). Academic Performance 5-factor Inventory. Ibadan: Stirling-Horden.

Awofala, A.O.A; Awofala, A.A; Fatade, A.O. \& Nneji, M. (2012). Determinants of Students' Achievement in Senior Secondary School Mathematics and Science: What is the role of test Responses made and Locus control? International Journal of Mathematics Trends and Technology, 3 (3): 125-130.

Boekaert, M; Otten, R; \& Voeten, R. (2003). Examination Performance: Are Students Causal Attributions School- Subject Specific? Anxiety, Stress and Coping, 16 (3): 331 342 .

Bong, M; \& Skaalvik, E. (2003). Academic Self Concept and Self-efficacy. How different are they really? Educational Psychology Review, 15: 1-40.

Carlson, N.R. (2007). Psychology: the science of Behaviors (4thed). Canada: Pearson Education.

Dollinger, S.J. (2000). Locus of Central and Incidental Leaning. An Application to College Success. College Student Journal, 34 (4): 537.

Downess. M. (2008). Locus of control as a correlate of Achievement in English as second Language in Ibadan. Journal of International Social Research, 4 (17): 547-549.

Gbonee, M.S. (2013). Study of Locus of Control on Academic Achievement among Students in Secondary Schools in Rivers State: The Case Study of Schools in Ogori Area. African Journal of African Education and Technology, 4 (1): 26-30.

Grimes, P.W; Millea, M.J, \& Woodruff, T.W. (2004). Grades Who's to Blame? Student Evaluation of Teaching and Locus of Control. The Journal of Economic Education, 35 (2): 29-47.

Hans, T. (2000). Am Meta-analysis of the Effects of Adventure Programming on Locus of Control. Journal of Contemporary Psychology, 30 (1): 33-60. 
Herbert, M. (1982). Locus of control: Current Trends in theory and Research. Psychology Press.

Jocobs-Lawson, J.M; Waddell, E.L. \& Webb, AK. (20011). Predicators of Health Locus of Control in older Adults; Current Psychology, 30(2): 173-183.

Leorne, R. \& Burns, T.E. (2000). Improved Reading through Connelly. Prentice Hall. PP.19

Mamlin, N.; Harris, K. R. \& L. P. (2001) A Methodological Analysis of Research on Locus of control and leaning Disabilities: Rethinking a Common Assumption. Journal of Special Education, Winter, 3 (4): 28.

Njus, D. M. \& Brockway. J.H. (1999). Perceptions of Competence and Locus of Control for Positive and Negative Outcomes. Personality and individual differences, 26: 531548.

Oludipe, B. B. (2013). Internal Verses External Control of Reinforcement: Where do Nigeria Science Students Belong? Journal of Education and Practice, 4 (9): 65-66.

Rotter, J. B. (1966). Generalized Expectancies for Internal Verses External Control of Reinforcement. Psychological Monographs, General and Applied, 80 (1): 1-26.

Rotter, J. B. (1975). Some Problems and Misconceptions Related to the Construct of Internal Verses External Control of Reinforcement. Journal of Consulting and Clinical Psychology, 43: 56-67.

Schultz, D.P \& Schultz, S.E. (2005). Theory of personality $\left(8^{\text {th }}\right.$ ed.) Wadswork: Thomson.

Sharmmen, N. (2004). Language attitude in Multilingual primary school in Fiji, Language, Culture and curriculum, 17 (2): 1-13.

Slagsvol, B.A. (2008). Age education and the gender gap in the sense of control. International Aging and Human Development, 67 (1): 25-42.

Tella, A; Tella, A. \& Adeniyi, O. (2009). Locus of Control, Interest in Schooling, Selfefficacy and Academic Achievement. Cypriot Journal of Educational Sciences, 4:169173.

Tucker, G.R; Hamayan, E. \& Genesse, FH. (2006). Effective Cognitive and Social Factors in Second Language Acquisition, Candan Modern Language Review, 32:214 26.

Vroom, V.H. (1964). Work and Motivation. John Wiley \& Sons, Inc.

Whyte, C. (1980). An Integrated Counseling and Learning Assistance Centre. New Directions sourcebook-learning Assistance centre. Jossey-Bass, Inc.

Yoloye, T.W.B (2004). That We May Learn Better. An Inaugural Lecture Presented on $7^{\text {th }}$ October. Pp 29. University of Ibadan. 
Zimemrman, B. (2000). Self-Efficacy: An Essential Motive to Learn. Contemporary Educational Psychology, 25 (1): 82-91. 